\title{
A Glancing Meteor of FinTech "Start-up" Business Model (Perspective Views of Italian, Turkish, and Indonesian Users)
}

\author{
Berto Usman* \\ University of Bengkulu
}

December 2, 2017

\footnotetext{
* Assistant Professor at the Department of Management, Faculty of Economics and Business, University of Bengkulu - Indonesia. E-mail: berto_usman@unib.ac.id

This paper is the preliminary results of descriptive analysis on the perception of respondents using Financial Technology (FinTech) in three different countries. I am grateful for comments and extensive discussions on conceptual and statistical method to Cecilia Rossignoli and Alessandro Zardini (University of Verona), Taha Eğri (Kırklareli Üniversitesi). The Indonesian Student Association in Turkey (PPI-Turkey), Indonesian Student Association in Italy (PPI-Italy) and David Brito (Universitario de Lisboa ISCTE-IUL, Lisbon Portugal) for the assistance in the process of data collection, and the contribution of participants at the $3^{\text {rd }}$ International Students Social Sciences Congress ( $3^{\text {rd }}$ Uluslararası Ögrenciler Sosyal Bilimler Kongresi) in Istanbul Medeniyet University, Turkey. Whilst, all the plausibility of mistakes and errors are mine.
} 


\title{
A Glancing Meteor of FinTech "Start-up" Business Model (Perspective Views of Italian, Turkish, and Indonesian Users)
}

\author{
This manuscript was presented at the $3^{\text {rd }}$ International Students Social Sciences \\ Congress ( $3^{\text {rd }}$ Uluslararası Ögrenciler Sosyal Bilimler Kongresi) on 2-3 \\ December 2017 in Istanbul Medeniyet University, Turkey \\ Berto Usman \\ Department of Management, Faculty of Economics and Business \\ University of Bengkulu \\ Jln. WR Supratman, Kandang Limun, Bengkulu - Indonesia \\ berto_usman@unib.ac.id
}

\begin{abstract}
The purpose of this study is to elaborate the usage of decomposed theory of planned behavior, in terms of users' perspective of utilizing financial technology (FinTech) application in startup firms. Hereby, there are 375 respondents participated in the online survey. The survey was conducted through several social media platforms namely; WhatApps, Messenger, Linkedln, e-mail and Line group. The targeted respondents are from Italy, Turkey, and Indonesia. In this study, the constructs are generated from the decomposed theory of planned behavior as developed by Shih \& Fang, (2004). Every indicator used in this research must be following several instrumental tests such as validity and reliability test. In order to get more knowledge and description about the different perceptions of users in three crosscountry tests, the correlation analysis and descriptive statistics analysis with countries' mean score are employed. According to the obtained results, it is noted that Italian mean score (3.61) in regard to behavior intention (BI) of using financial technology application as the product of FinTech startup firms is relatively higher than the mean scores of Turkish (3.27) and Indonesian users (3.27).
\end{abstract}

Keywords: Financial technology, Decomposed theory of planned behavior 


\section{INTRODUCTION}

For the last decades, the form of business operation has significantly changed along with the remarkable progress of information communication technology (ICT). Even in the field of management business, more companies have transformed the way they run their business forms from the analog system to the digitalized oriented-system (Hoon \& Lee, 2015; Nurazi, Kananlua, \& Usman, 2015; Nurazi \& Usman, 2015; Usman \& Tandelilin, 2014). In the field of financial industry, it has been a long story that ICT is determined as one of the most important key success factors to boost the firm performance. However, it has been a matter of debate whether ICT will be truly able to result in better financial success story or not. As considered by Sharma, (2012) there is no conclusive evidence that spending on ICT contributes to the increase of financial performance. He notices that in the case of the technological induction period, the low and high period incline to result in the different performance, in which the fully ICT oriented banks are financially better off than the partially oriented ICT banks. On the other hand, in order to disrupt the awkward system of financial industry, the phenomenon of Financial Technology "FinTech" emerges as one of the new market niches in the area of financial industry (Mellon, 2015).

Wentzel, Diatha, \& Yadavalli, (2013) and Hoon \& Lee, (2015) point out that there is currently a huge expansion of products and services delivery which can be transported through technology utilization. Some of the sophisticated gadgets such as smartphone, tablet, laptop which are connected to the internet have lead the users to a new style of self-service processing standard. Technology platforms as provided by the providers and technological vendors enable the users experiencing the product consumption in more innovative ways. Moreover, the usage of technology can also be attributed to saving efforts, transfer, payments, and money circulation among the users (Lussier, 1996). Thus, in this circumstance users as the consumers are being facilitated by technological easiness.

World Economic Forum (WEF), in 2015 reports that the current model of financial technology (hereinafter written as FinTech) business operation inclines to challenge the traditional sector and practices of financial service activities. At this moment, the computer and technological innovation have transformed the societies and the economies itself. This phenomenon is revealed by the WEF, (2015) which studies the progress of technological innovation and its contribution towards economic activity. Since the last 15 years, the world is being more connected, in which the tech-led innovation is currently challenging the established industries that have been playing for a long-term in the financial industry. It shows that financial innovation regarding its collaboration with technology has already been leading the environment to experience and being included in a massive change in financial 
services activity (Au \& Kauffman, 2008; Nurazi, Usman, \& Kananlua, 2016; Philippon, 2016). Therefore, in line with the argument of Chishti \& Barberis, (2016) financial technology is supposed to disrupting the process and the way of financial services being offered into a quite contemporary access, and to underserved markets in more unique, easy and new methods for the financial service users.

In organizational views, the emerging of a business entity within an industry can be attributed to population theory. Referring to the population theory, it is noted that a new business entity should have to imitate the way of the established business entities operating their businesses. This is important to get the most effective and efficient method in doing a business operation (Baum \& Shipilov, 2006). Therefore, the new startup business will effectively gain their legitimacy among the players. However, a quite bit different condition can be found in terms of financial startup firms, in which this business try to combine financial and technological factors as its competitive advantage (Dapp, 2014; Vasiljeva \& Lukanova, 2016). The FinTech startup firms do not independently play as a player in the financial industry. FinTech focuses on bridging the needs of the market which has no connection to bank services (Chishti \& Barberis, 2016). There is a special and unique market niche in this issue, where FinTech startup business will be able to gain more advantage in this specific marketplace.

On the side of users' perspective, the fast transformation and combination between financial and technological industry incline to result in a new lifestyle, particularly in the form of personal financial management. Some studies in the area of financial psychology mention that the intention of users to use either new service or product commonly can be described by employing the model of theory reasoned action (TRA) and theory of planned behavior (TPB) (Ajzen, 1985, 1991). These two theories are broadly utilized to reveal the behavior along with the action and individual intention either toward particular services or products. Moreover, Bobbitt \& Dabholkar, (2001) also conduct a specific study about technology based-self-service. Their research studies on a conceptual framework with respect to the attitudinal theories. They find that the use of internet can be represented as a measured of consumer behavior, where the consumers' decision which related to technology based-self-service is determined as an underlying factor of consumer attitude.

Before the FinTech phenomenon rapidly emerges, most of the consumers are depending on banking services and products (see. Dapp, 2014; Sironi, 2016; Usman \& Tandelilin, 2014). Take, for instance, the intention of consumers can be measured by employing TRA and TPB. However, a relatively new and contemporary model is developed and known as the decomposed theory of planned behavior (Shih \& Fang, 2004). The study of Shih \& Fang, (2004) finds that the decomposed theory 
of planned behavior is better in explaining the users' intention compared to TRA and TPB on using the product of internet banking in Taiwan. More comprehensively, Ricciardi, Rossignoli, \& Zardini, (2013) do meta-analysis research with 106 writings in the relevant area of information technology and strategic value for the organization. They note that IT-enabled latent strategic capabilities are severely under-investigated by theory testing writings, and even IT-enabled competitive advantage. Therefore, this study also wants to take a position concerning the works of literature in regard to the FinTech as a phenomenon in the 21st century of startup business models.

Particularly, this study contributes to several key point areas concerning the glancing number of FinTech companies and the users' perception of using the FinTech application. First, the usage of decomposed theory of planned behavior is clearly needed, particularly to describe the current and reliable results of users' assessment toward the utilization of FinTech service and products. Second, the decomposed model of the theory of planned behavior as developed by Shih \& Fang, (2004) highlights several empirical analysis results by employing subject from the different geographical area. Third, this study provides thorough data collection which is conducted through specific exploration and investigation on primary, secondary data of FinTech companies, and their users' perception. Fourth, this study primarily contributes to the extent literature which provides the theoretical and empirical result of the financial technology startup business model.

To comprehensively elaborating the phenomenon of "a glancing meteor of FinTech startup business model", this paper addresses some research questions. First, how is the current condition of FinTech startup business model? Second, how are the common demographical profiles of FinTech users in three countries (Italy, Turkey, and Indonesia)? Third, how is the perception of users in regards to their intention to use the FinTech services and products? In this study, Italy, Turkey, and Indonesia have been determined as the targeted objects due to their economic connection, which is integrated with technology development in financial industry, especially in their regional economy areas in the European Union (EU), Middle East Network, and ASEAN Economic Community.

Further, the remainder of this paper is structured into several sections. Section of introduction elaborates the standpoint, the background, contribution, and research questions with respect to the FinTech startup business model. The section of literature review deeply explains the major theoretical foundations of the current FinTech, particularly in the form of startup business model. Section research and method meticulously provide the method of data collection and its quantitative elaboration. Section results and discussion are needed to delivering the common 
results and typical characteristics of respondents' perspective as the users of FinTech application. The last section is conclusion remarks, which presents the general conclusion and implication about this study.

\section{LITERATURE REVIEW}

\section{Start-up Business Model}

The form of startup companies, or known as "startup" or "start-up", according to Robehmed, (2013) is defined as an entrepreneurial venture. This business is basically a newly emerged, and appears as the fast-growing business that particularly has the objective to meet the market needs in the way of creating or proposing innovative products, processes or services. Also, as concerned by Robehmed, (2013) and Lueg, Malinauskaite, \& Marinova, (2014) the form of startup commonly started in small-business scale, which sometimes attributed to the partnership or a specific organization form to create the fast development of business scale.

Nkongolo-Bakenda, (2002) points out that a startup firm should have to build a strong relationship with its affiliated firms. In this case, startup firm will be able to outsource some specific activities, especially for several operations which could not be completed by the startup itself. In order to enforce the characteristic of startup firm, in their previous study Hunt \& Morgan, (1995) explicitly show that the infant startup firms can be started just in case if the firms try to capitalize on an invention. In this situation, startup firms might not be able to optimally and internally utilizing their asset, and even they probably incurred by the lack of asset due to the business operation which is operated without any partners. Moreover, Kask \& Linton, (2013) note that business relationship among startup firms is important and critical to fostering the prosperity of startup itself.

Solaimani \& Bouwman, (2012) in their study report that most of the startup firms will be failed before they reach the fifth years of business operation. This is due to the lack of business model that should have to be aligned along with the operational and actual business of startup firms. Therefore, the study of Lueg, Malinauskaite, \& Marinova, (2014) tries to convince that several problems appear from the lack knowing of target consumers and the value which is offered by the startup toward its consumers. Also, the problem of human resources and insufficient information system are considered as the causing factors of startup business failed. In the FinTech startup firms, the factor of human resources and information system are the key success factors in achieving and gaining survivorship for the long-term period of business operation (Hoon \& Lee, 2015). 


\section{Financial Technology}

The terminology of "Financial Technology", which is also known by its acronym as "FinTech" emerges as the new business model with the effort to disrupt the traditional financial service systems (Chishti \& Barberis, 2016; Hoon \& Lee, 2015). In this case, FinTech tries to evolve the way of people in handling their money and the banking in terms of managing personal and business lives. In the field of financial industries, including in the model of financial technology business operation, there are four major roles where financial firms contribute in economy; (i) financial companies facilitating risk diversification, (ii) providing service payments, (iii) creating credits, and (iv) managing the wealth of investors along with its risks. In more specific ways, according to International Trade Administration or ITA, (2016), FinTech startup firms generally play in a special market niche. This market niche is known as payment services. This niche is reported as the highest adoption rate among FinTech startup firms all around the world following by saving, investment, insurance service, and online borrowing (ITA, 2016).

To explain the way of FinTech plays in the financial industry, ITA, (2016) performs the method of FinTech firms disrupting financial technology scheme. In this situation, the model of traditional financial institution is being challenged. First, financial technology firms tend to compete with an alternative model of the network of financial providers. Hereby, a particular network which offers the innovative model of financial services is clearly needed. Second, the activity of facilitating financial services is conducted as complements, where traditional institutions which release their products can be integrated with the alternative finance scheme ecosystem (Dapp, 2014). In this circumstance, traditional financial institutions act as the gateway to the model of alternative financial services scheme. Third, FinTech startup firms focus on preparing more products option within the existing financial institution. In this regard, the alternative financial model needs to be developed as a new solution in financial service as offered to users. As noted by Hoon \& Lee, (2015) the most common field of business entered by FinTech startup firms is payments that can be attributed to digital currencies, insurance/health, lending, crowdfunding, wealth management, retail banking and others.

\section{The Existence of Global Financial Technology}

According to the data of McKinsey's Proprietary Panorama FinTech Database, there is a significant number of FinTech launched in the recent years. Here, the focuses of FinTech are concentrated on the utilization of technology to conduct the fundamental functions and operation prepared by the activity of financial services. Therefore, most of FinTech startup firms bring a new way to consumers about storing, saving, borrowing, investing, moving, paying and protecting their money in more modern and digitalized system. As shown by the data of McKinsey, (2015) 
which is obtained and managed by employing approximately around 800 FinTech startups in global, FinTech startup firms are undoubtedly having a significant momentum in this field of business activity. In terms the number of venture capital and its growth equity, there is around $\$ 23$ billion has been deployed to FinTech for a half-decade of time (see Figure 1).

Figure 1. Customer segments and products of leading FinTech, 2015

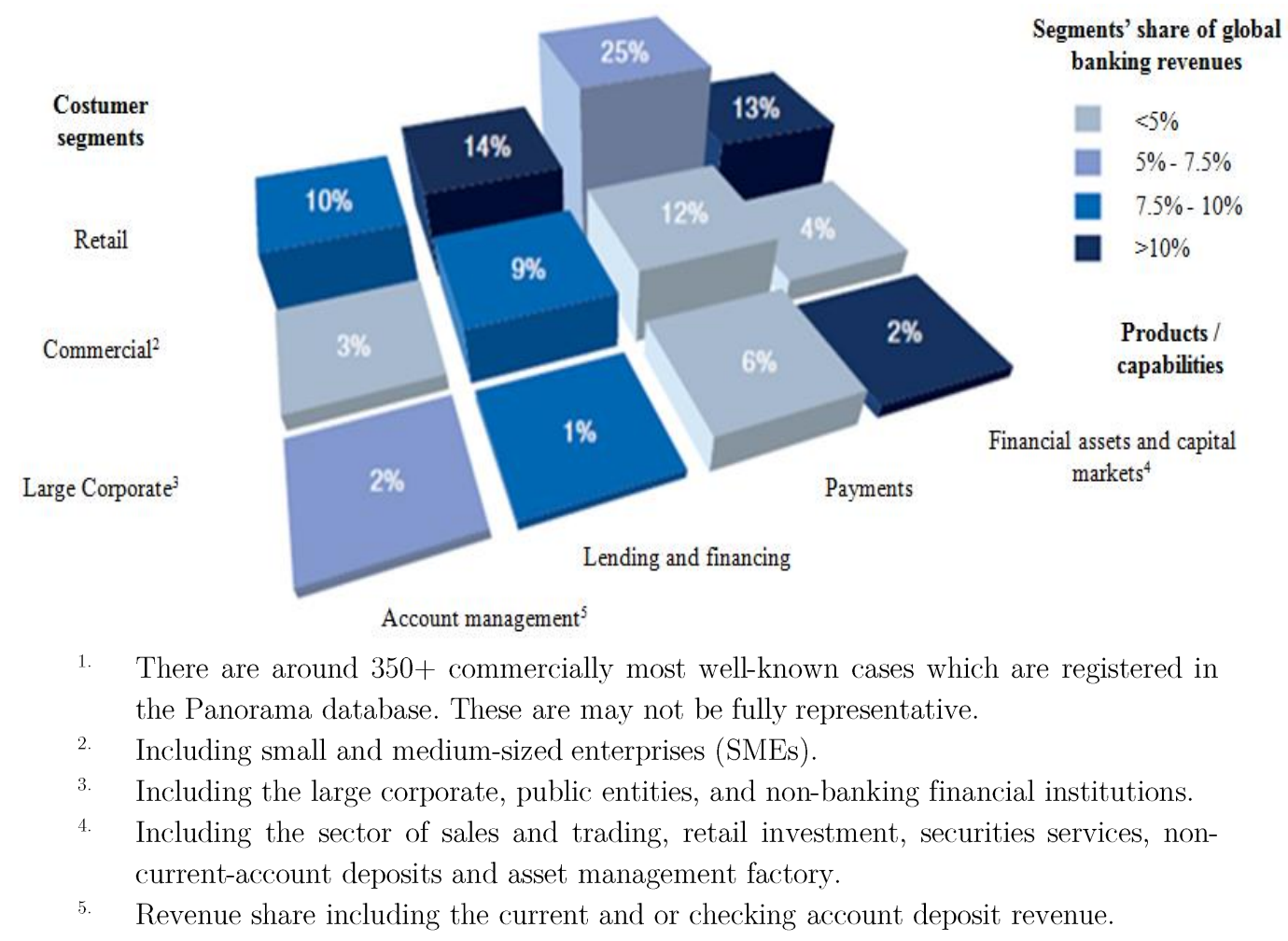

Source: (McKinsey, 2015)

The existence of FinTech startup business all around the world is also driven by the market trends and industrial changes. Technology adoption as a new way and its impact as a new tool and solution are rapidly widespread (Dapp, 2014; Hoon \& Lee, 2015). Here, the breakneck rate of adoption of technology in financial service products is itself acting as a tremendous driver of change in market trend. Also, the turmoil circumstance after the global financial crisis prompted the introduction of new regulation in restoring consumer confidence in the banking industry (Alfansi \& Sargeant, 2000; Kamaludin, Darmansyah, \& Usman, 2015; Nurazi \& Usman, 2016). Therefore, the industrial change has led to a more transparent and visible data processing. In this situation, Mellon, (2015) points out that outcome of the increased transparency and data visibility which in turn aids cash management and generating more cost saving for the client. 


\section{Decomposed Theory of Planned Behavior and its Relation to Financial Tech- nology}

Theory of planned behavior or commonly known as TPB is a theory which is extended from the theory of reasoned action (Fishbein, M. \& Ajzen, 1975). TPB is further exposed by Ajzen, (1991) in which he wants to reveal the intention of an individual to do some specific action, including investigating and identifying the users' intention. As the globalization exists in the area of financial service, financial and technology no longer becomes something new for the global population. Even in terms of organizational theory perspective, a new business model will be emerged as the market niche still widely opened. Here, it can be easily observed that FinTech plays in the ecosystem of the financial industry (Dapp, 2014; Hoon \& Lee, 2015). Therefore, the emerging financial firms known as startup firms are intriguing to be comprehensively explored. The response of users and their intention to use specific services or products can be well-explained by employing the theory of planned behavior (Luor, Lu, Johanson, \& Yu, 2012). The common theory of planned behavior consisting of some important factors such as attitudinal belief which corresponds to attitude, normative belief relates to the subjective norm, and control belief which attributes to perceived behavioral control (Ekufu, 2012). All of these factors are employed in order to explain the behavior intention of using specific services or products, that contributes to the actual usage of services or products itself.

Figure 2 The pure form of the theory of planned behavior (TPB)

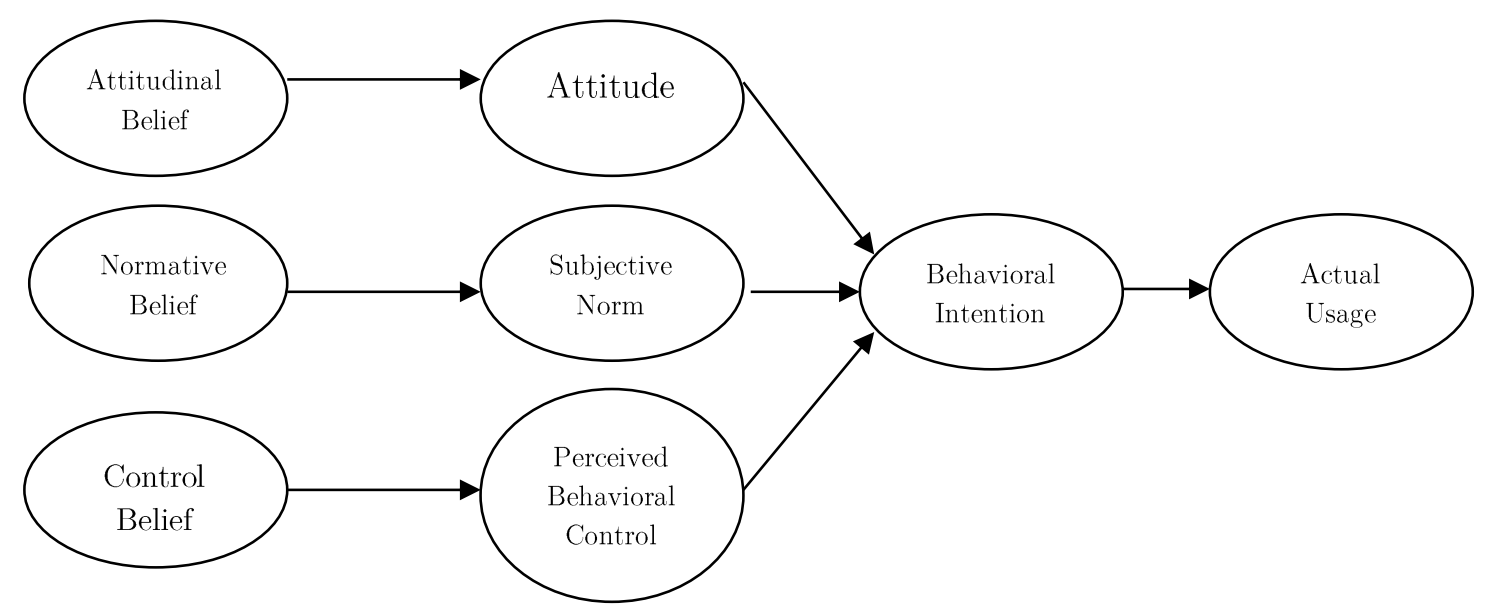

Source: Shih \& Fang, (2004).

As previously explained, the theory of planned behavior (TPB) is the extended model of theory reasoned action (TRA), which adds perceived behavior control as a factor that is envisaged contributing to the intention and behavior. Hereby, 
Ajzen, (1991) clearly defines perceived behavior as the ease or difficulty of performing the behavior interest on a certain activity. Current research has obviously shown that the factor of perceived behavioral control is relevant to explain the interest of using technological products. As pointed out by Bobbitt \& Dabholkar, (2001), the variation of technology-based self-service can be explained by employing the model of the theory of planned behavior. Further, the study of Shih \& Fang, (2004) decomposes TPB into the decomposed model of TPB as can be observed as follow.

Figure 3 Theory of planned behavior with belief decomposition

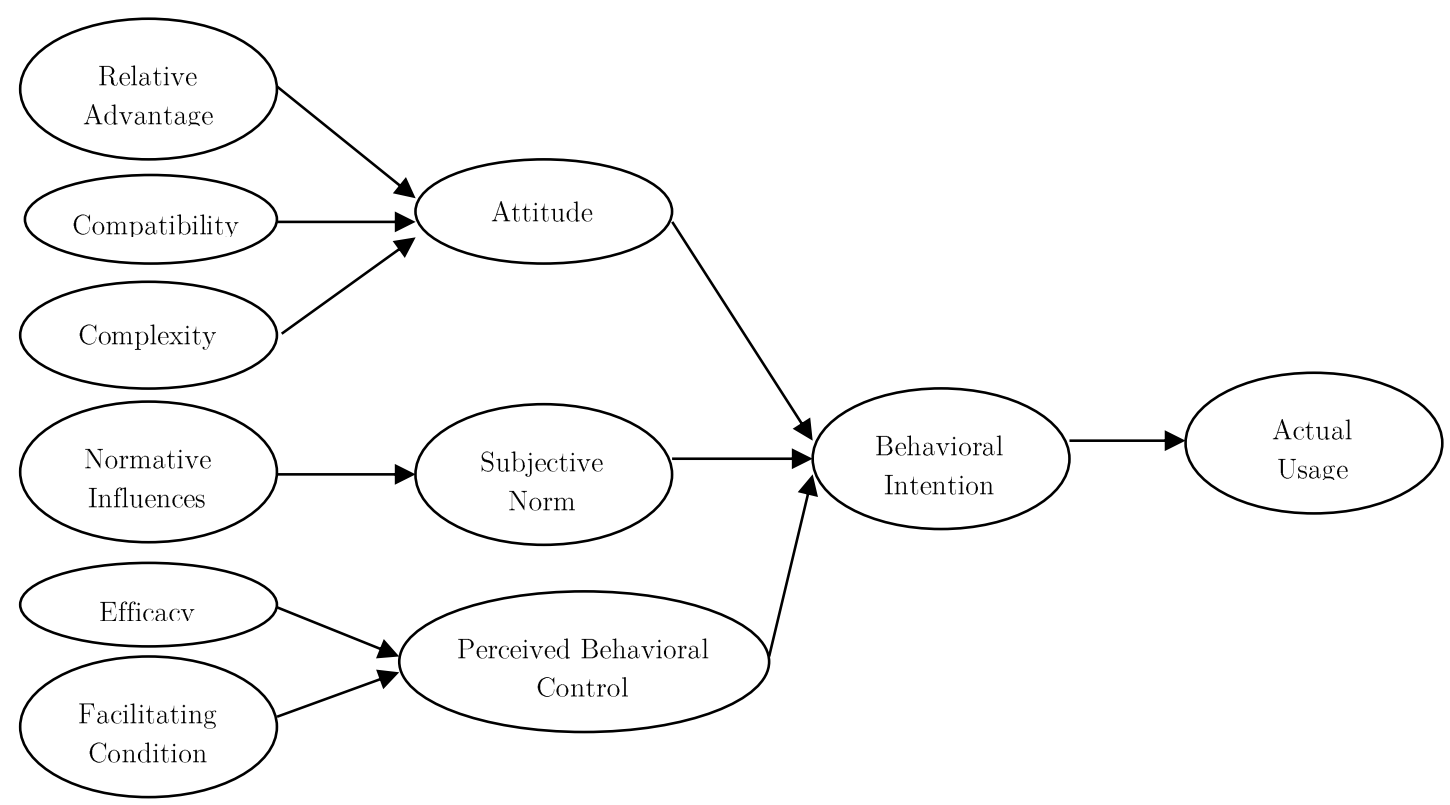

Source: Shih \& Fang, (2004).

The model of decomposed theory of planned behavior as reflected in Figure 2 is developed from the main theory of planned behavior of Ajzen, (1991). At first, the antecedents of intention need to be well-explained by a clear belief structure (Taylor \& Todd, 1995). Therefore, the decomposition of attitudinal beliefs has firstly been developed by Shimp \& Kavas, (1984). Their study reports that cognitive components of belief will only be possible to be structured into several cognitive units. In regard to this issue, Taylor \& Todd, (1995) have previously explained that the decomposed model of the theory of planned behavior has a particular power in explaining the extension of the theory of planned behavior (TPB) and theory of reasoned action (TRA).

In more comprehensive elaboration, the construct of relative advantage (RA) corresponds to which level of innovation able to serve the benefit of users. Rogers, 
(1995) argues that relative advantage (RA) is positively attributed to the rate of innovation adoption among the service or products users. By adopting the financial technology application as provided by the startup firms, the easiness of using financial service can be experienced without any limitation in regard to time and space limitation (Philippon, 2016). Moreover, compatibility is noted as the extent to which innovation developed by service providers able to fit the current needs and experiences of users (Tan \& Teo, 2000). While complexity denotes as the representation of innovation level, particularly concerning the level of difficulties about how to operating, using, and learning the new features as provided by the product developers (Shih \& Fang, 2004).

Further, normative influence (NI) and subjective norm (SN) indicate the individual's perception of social pressure by attachment figures to carry out or refrain from the focal behavior (Usman, 2016). While perceived behavior control (PBC) represents individual's perceived capability to conduct the intended behavior of related services or product. Efficacy as one of the decomposed constructs in TPB model corresponds to the level of confidence, particularly in the form of ability to behave in a certain condition. In this case, the users' confidence in their ability to use the financial technology application is measured by employing efficacy. Also, facilitating condition denotes as the availability of the required resources to perform a particular and specific behavior (Shih \& Fang, 2004).

\section{RESEARCH METHOD}

\section{Subjects}

This research is a quantitative research, which focuses on examining the phenomenon based on the empirical testing procedures. The data in this study is also collected by employing online questionnaire (the link of online survey through Google Form can be retrieved on: https://goo.gl/forms/LynrtTICuEbudKjI3). The online questionnaire is distributed to respondents who live in the different countries. Some social networking media are utilized in the process of data collection. Hereby, the questionnaires are posted through WhatApps, Facebook, Messenger, Linkedln, Email and Line groups of respondents who stay in three countries (Italy, Turkey and Indonesia) and actively act as the users of financial technology application.

\section{Measurements}

In this study, the model of decomposed theory of planned behavior as developed by Shih \& Fang, (2004) is employed. The theory of reasoned action (TRA) and theory of planned behavior (TPB) are developed as of the model of decomposed planned behavior emerges. In order to get accurate measurements from the respondents, the previous studies with respect to TRA and TPB are extensively and 
comprehensively identified, which finally result in the final decomposed model. As many as ten decomposed beliefs refer to the model of Shih \& Fang which consist of (i) behavioral intention to use (BI), (ii) attitude toward using (A), (iii) relative advantage (RA), (iv) compatibility (C1), (v) complexity (C2), (vi) normative influence (NI) (vii) subjective norm (SN), (viii) perceived behavior control (PBC), (ix) efficacy (E), and (x) facilitating condition (F). The questionnaire employed in this study also performed a five-point Likert-scale in measuring the perception of respondents toward the developed constructs.

\section{RESULTS AND DISCUSSION}

\section{Demographical of Respondents}

The number of subjects gathered as the respondents in this study is 375 respondents. There are three groups of respondents who participated in the online survey. Here, this research collects as many as 125 respondents from Italy, and the same number from Turkey and Indonesia as well. Most of the respondents who participated in this study are international students who are studying and working in those three countries. In order to specifically elaborate the current profiles of respondents, the descriptive analysis method is employed. The common investigation is started toward the six basic questions of respondents' profiles. This information is further provided in the form of frequency analysis in three separated cases of Italian, Turkish, and Indonesian setting as can be seen as follows. 
Table 1. Demographic profiles of respondents in three countries

\begin{tabular}{|c|c|c|c|c|c|c|c|}
\hline \multirow{2}{*}{ Measures } & \multirow{2}{*}{ Value } & \multicolumn{2}{|l|}{ Italy } & \multicolumn{2}{|c|}{ Turkey } & \multicolumn{2}{|c|}{ Indonesia } \\
\hline & & Frequency & $(\%)$ & Frequency & $(\%)$ & Frequency & $(\%)$ \\
\hline \multirow[t]{2}{*}{ Gender } & Male & 49 & 39.2 & 74 & 59.2 & 61 & 48.2 \\
\hline & Female & 76 & 60.8 & 51 & 40.8 & 64 & 51.2 \\
\hline$\Sigma$ & & 125 & 100 & 125 & 100 & 125 & 100 \\
\hline \multirow[t]{4}{*}{ Age } & $<20$ & 14 & 11.2 & 31 & 24.8 & 14 & 11.2 \\
\hline & $21-30$ & 70 & 56 & 78 & 62.4 & 88 & 70.4 \\
\hline & $31-40$ & 41 & 32.8 & 15 & 12 & 23 & 18.4 \\
\hline & $41-60$ & & & 1 & 0.8 & & \\
\hline$\sum$ & & 125 & 100 & 125 & 100 & 125 & 100 \\
\hline \multirow[t]{2}{*}{ Status } & Worker & 9 & 7.2 & 14 & 11.2 & 53 & 42.4 \\
\hline & Student & 116 & 92.8 & 111 & 88.8 & 72 & 57.6 \\
\hline$\sum$ & & 125 & 100 & 125 & 100 & 125 & 100 \\
\hline \multirow[t]{4}{*}{ IE } & $<1$ & 3 & 2.4 & 4 & 3.2 & 1 & 0.8 \\
\hline & $1-3$ & 1 & 8 & 12 & 9.6 & 15 & 12 \\
\hline & $4-6$ & 8 & 6.4 & 16 & 12.8 & 39 & 31.2 \\
\hline & $>6$ & 113 & 90.4 & 93 & 74.4 & 70 & 56 \\
\hline$\Sigma$ & & 125 & 100 & 125 & 100 & 125 & 100 \\
\hline \multirow[t]{4}{*}{ DUFTA } & 0 time & 23 & 18.4 & 44 & 35.2 & 50 & 40 \\
\hline & $1-5$ & 59 & 47.2 & 41 & 32.8 & 50 & 40 \\
\hline & $6-10$ & 3 & 2.4 & 13 & 10.4 & 10 & 8 \\
\hline & $>10$ & 40 & 32 & 27 & 21.6 & 15 & 12 \\
\hline$\Sigma$ & & 125 & 100 & 125 & 100 & 125 & 100 \\
\hline \multirow[t]{4}{*}{ UFFTA } & $<1$ week & 56 & 44.8 & 70 & 56 & 65 & 52 \\
\hline & $2-3$ & 25 & 20 & 14 & 11.2 & 18 & 14.4 \\
\hline & $4-6$ & 8 & 6.4 & 9 & 7.2 & 13 & 10.4 \\
\hline & $>1$ month & 36 & 28.8 & 32 & 25.6 & 29 & 23.2 \\
\hline$\Sigma$ & & 125 & 100 & 125 & 100 & 125 & 100 \\
\hline
\end{tabular}

Notes:

IE : Internet Experience

DUFTA: Degree of Using Financial Technology Application

UFFTA: Using Frequency of Financial Technology Application

Table 1 displays the demographical profiles of respondents. There are totally 375 respondents participated in the online survey. Each of cross-country survey data shows a bit different results in terms of their demographical profiles. According to the data in Table 1, it is known that majority respondents who give their responses in Italy are dominated by female as 60.8 percent or equal to 76 respondents, and 
the number of male respondents is 39.2 percent or equals to 49 people. While in Turkey, the number of respondents shows a reciprocal condition, in which Turkey's respondent is dominated by the male as 59.2 percent and followed by 40.8 percent female. Indonesia as the last country performed a more balanced composition in its respondents, where there are 48.2 percent males and 51.2 percent females participated.

In terms of age, most of the respondents in this study are categorized between 2130 years-old users ( 56 percent in Italy, followed by 62.4 in Turkey and 70.4 percent in Indonesia respectively). Then, the second dominating users are classified as respondents in the group of 31-40 years-old. This information denotes that virtually all of respondents are financially independent in managing financial life and being actively using technology as a part of their personal financial management life. This notion also supported by the fundamental information, that most of the respondents from these three countries are international students who study in different graduate programs.

Moreover, the internet experience (IE) of users is also considered as the factor when they were determined as respondents. Only those who know and familiar with technology can be included as respondents. In Italy, 90.4 percent of respondents have been classified as the regular user of the internet for more than 6-years. This condition is different from Turkey and Indonesia, in which Turkey's respondents who have more than 6-year internet experience is 74.4 percent, and followed by Indonesian respondents as 56 percent. In more specific condition, the degree of using FinTech application (DUFTA) is also measured. Here, the users' degree of using some financial technology applications such as MoneyGram, Paypal, TransferWise, and so forth. is calculated based on how many times they ever use it. According to the data in Table 1, it is known that Italian users actively use financial technology application from 1 to 5 times as 47.2 percent, and 32 percent use it for more than ten times on average. In Turkey and Indonesia, half of the respondents have never been trying to use the products of FinTech because they tend to be more connected with bank services rather than independently using FinTech application. Further, in terms of using frequency of FinTech application, respondents from Italy (44.8 percent), Turkey (56 percent) and Indonesia (52 percent) have the same tendency, in which their frequency of using of FinTech application is less than a week.

In order to get the accurate measurements, every indicator in this study needs to be tested by using validity and reliability tests. Validity test is performed by employing rank spearman correlation test, while reliability test is conducted by utilizing Cronbach alpha test. Here, there are ten constructs used as the breakdown of decomposed theory of planned behavior. These constructs are RA (Relative 
Advantage), C1 (Compatibility), C2 (Complexity), A (Attitude), NI (Normative Influence), SN (Subjective Norm), E (Efficacy), F (Facilitating Condition), PBC (Perceived Behavior Control) and BI (Behavior Intention). Each of construct also established by forming some specific indicators of questions as depicted in Table 2 .

Table 2. Cronbach alpha test results (reliability analysis for each construct)

\begin{tabular}{|c|c|c|c|c|}
\hline \multirow{2}{*}{ Construct } & \multirow{2}{*}{ Item } & \multicolumn{3}{|c|}{$\alpha$-value } \\
\hline & & Italy & Turkey & Indonesia \\
\hline RA & & 0.933 & 0.945 & 0.967 \\
\hline RA.1 & $\begin{array}{l}\text { Using Financial Technology application } \\
\text { would save time. }\end{array}$ & & & \\
\hline RA.2 & $\begin{array}{l}\text { Using Financial Technology application } \\
\text { would save time, and it is important to me. }\end{array}$ & & & \\
\hline RA.3 & $\begin{array}{l}\text { Using Financial Technology application has } \\
\text { more advantages. }\end{array}$ & & & \\
\hline RA.4 & $\begin{array}{l}\text { Using Financial Technology application has } \\
\text { more advantages, and it is important to me. }\end{array}$ & & & \\
\hline C1 & & 0.958 & 0.968 & 0.975 \\
\hline C1.1 & $\begin{array}{l}\text { Using Financial Technology application will } \\
\text { fit well with my lifestyle. }\end{array}$ & & & \\
\hline $\mathrm{C} 1.2$ & $\begin{array}{l}\text { The Financial Technology application will fit } \\
\text { well with my lifestyle, and it is important to } \\
\text { me. }\end{array}$ & & & \\
\hline $\mathrm{C} 1.3$ & $\begin{array}{l}\text { Using Financial Technology application will } \\
\text { fit well with how I use it. }\end{array}$ & & & \\
\hline C1.3 & $\begin{array}{l}\text { The Financial Technology application will fit } \\
\text { well with how I use it, and it is important to } \\
\text { me. }\end{array}$ & & & \\
\hline $\mathrm{C} 2$ & & 0.880 & 0.911 & 0.940 \\
\hline $\mathrm{C} 2.1$ & $\begin{array}{l}\text { Financial Technology application is easy to } \\
\text { learn. }\end{array}$ & & & \\
\hline $\mathrm{C} 2.2$ & $\begin{array}{l}\text { Easy to learn Financial Technology is } \\
\text { important to me. }\end{array}$ & & & \\
\hline $\mathrm{C} 2.3$ & $\begin{array}{l}\text { Financial Technology application is easy to } \\
\text { operate. }\end{array}$ & & & \\
\hline $\mathrm{C} 2.3$ & $\begin{array}{l}\text { Easy to operate Financial Technology appli- } \\
\text { cation is important to me. }\end{array}$ & & & \\
\hline $\mathrm{C} 2.4$ & $\begin{array}{l}\text { Financial Technology application is easy to } \\
\text { learn. }\end{array}$ & & & \\
\hline A & & 0.934 & 0.947 & 0.928 \\
\hline A. 1 & $\begin{array}{l}\text { I feel using Financial Technology application } \\
\text { (e.g., PayPal, MoneyGram, TransferWise, } \\
\text { etc.) is a wise idea. }\end{array}$ & & & \\
\hline
\end{tabular}




\begin{tabular}{llc}
\hline \multirow{2}{*}{ Construct } & Item & \multicolumn{2}{c}{$\alpha$-value } \\
\cline { 3 - 3 } & & Italy Turkey Indonesia \\
\hline
\end{tabular}

A.2 I feel using Financial Technology application is a good idea.

A.3 I like to use Financial Technology application.

NI

NI.1 My family would think that I should use Financial Technology application.

NI.2 Generally, I want to do what my family thinks I should do.

NI.3 Most people would think that I should use Financial Technology application.

NI.4 Generally, I want to do what most people think I should do.

SN.1 Most people who are important to me would think that using Financial Technology application is a wise idea.

SN.2 Most people who are important to me would think that using Financial Technology application is a good idea.

SN.3 Most people who are important to me would think I should use Financial Technology application.

SN.4 My families who are important to me would think that using Financial Technology application is a wise idea.

SN.5 My families who are important to me would think that using Financial Technology application is a good idea.

SN.6 My families who are important to me would think I should use Financial Technology application.

E.1 I could easily to operate Financial Technology application on my own.

E.2 Being able to operate Financial Technology application is important to me.

E.3 I know enough to operate Financial Technology application.

E.4 Knowing enough to operate Financial Technology application is important to me.

E.5 I would feel comfortable using Financial Technology application. 


\begin{tabular}{|c|c|c|c|c|}
\hline \multirow{2}{*}{ Construct } & \multirow{2}{*}{ Item } & \multicolumn{3}{|c|}{$\alpha$-value } \\
\hline & & Italy & Turkey & Indonesia \\
\hline E. 6 & $\begin{array}{l}\text { Being comfortable using Financial Technol- } \\
\text { ogy application on my own is important to } \\
\text { me. }\end{array}$ & & & \\
\hline \multirow[t]{7}{*}{ F } & & 0.874 & 0.907 & 0.953 \\
\hline & $\begin{array}{l}\text { I have the network to use Financial Technol- } \\
\text { ogy application. }\end{array}$ & & & \\
\hline & $\begin{array}{l}\text { Having the network to use Financial Tech- } \\
\text { nology application is important to me. }\end{array}$ & & & \\
\hline & $\begin{array}{l}\text { I have the time to use Financial Technology } \\
\text { application. }\end{array}$ & & & \\
\hline & $\begin{array}{l}\text { Having the time to use Financial Technology } \\
\text { application is important to me. }\end{array}$ & & & \\
\hline & $\begin{array}{l}\text { I have enough money to use Financial Tech- } \\
\text { nology application. }\end{array}$ & & & \\
\hline & $\begin{array}{l}\text { Having enough money to use Financial Tech- } \\
\text { nology application is important to me. }\end{array}$ & & & \\
\hline PBC & & 0.920 & 0.948 & 0.959 \\
\hline PBC.1 & $\begin{array}{l}\text { I would be able to operate Financial Tech- } \\
\text { nology application. }\end{array}$ & & & \\
\hline PBC. 2 & $\begin{array}{l}\text { I have the resources to use Financial Tech- } \\
\text { nology application. }\end{array}$ & & & \\
\hline PBC.3 & $\begin{array}{l}\text { I have the knowledge to use Financial Tech- } \\
\text { nology application. }\end{array}$ & & & \\
\hline PBC. 4 & $\begin{array}{l}\text { I have the ability to use Financial Technol- } \\
\text { ogy application. }\end{array}$ & & & \\
\hline \multirow[t]{2}{*}{ BI } & & 0.908 & 0.906 & 0.928 \\
\hline & $\begin{array}{l}\text { I plan to use Financial Technology applica- } \\
\text { tion (e.g., PayPal, MoneyGram, Transfer- } \\
\text { Wise, etc.) }\end{array}$ & & & \\
\hline BI.2 & $\begin{array}{l}\text { I intend to use Financial Technology appli- } \\
\text { cation within the next three months. }\end{array}$ & & & \\
\hline BI.3 & $\begin{array}{l}\text { I intend to use Financial Technology appli- } \\
\text { cation within the next three months. }\end{array}$ & & & \\
\hline
\end{tabular}

After meticulously conducting the validity and reliability test, it is finally known that all indicators in this study are valid and reliable. The validity test through correlation analysis of each indicator as the formative indicators of constructs performs good correlation, in which this denotes that each indicator used in this study has already proven to measure what it should have to measure accurately. Also, the next step of validity test should be continued by applying reliability test. This test is performed by utilizing 
Cronbach alpha test. As a result of this, it is noted that most of the Cronbach alpha value ( $\alpha$ value) in cross-country data are above 0.80 on average. This denotes that all indicators used in this study are reliable to measure what it needs to measure. For further steps, it is necessarily important to investigate the correlation between each construct. Therefore, the correlation of each construct is provided in Table 3 as follow.

Table 3. Summary of inter-correlation analysis between each variable in consolidated data

\begin{tabular}{cllllllllll}
\hline Variables BI & A & SN & PBC & RA & C1 & C2 & NI & E & F \\
\hline BI & 1.000 & & & & & & & & & \\
& 0.000 & & & & & & & & & \\
$\mathrm{~A}$ & $0.724^{* *} 1.000$ & & & & & & & & \\
& 0.000 & 0.000 & & & & & & & & \\
SN & $0.489^{* *}$ & $0.604^{* *}$ & 1.000 & & & & & & & \\
& 0.000 & 0.000 & 0.000 & & & & & & & \\
PBC & $0.623^{* *}$ & $0.601^{* *}$ & $0.378^{* *}$ & 1.000 & & & & & & \\
& 0.000 & 0.000 & 0.000 & 0.000 & & & & & & \\
RA & $0.688^{* *}$ & $0.785^{* *}$ & $0.569^{* *}$ & $0.632^{* *}$ & 1.000 & & & & & \\
& 0.000 & 0.000 & 0.000 & 0.000 & 0.000 & & & & & \\
C1 & $0.666^{* *}$ & $0.769^{* *}$ & $0.595^{* *}$ & $0.613^{* *}$ & $0.783^{* *}$ & 1.000 & & & & \\
& 0.000 & 0.000 & 0.000 & 0.000 & 0.000 & 0.000 & & & & \\
C2 & $0.564^{* *}$ & $0.634^{* *}$ & $0.476^{* *}$ & $0.678^{* *}$ & $0.693^{* *}$ & $0.673^{* *}$ & 1.000 & & & \\
& 0.000 & 0.000 & 0.000 & 0.000 & 0.000 & 0.000 & 0.000 & & & \\
NI & $0.430^{* *}$ & $0.490^{* *}$ & $0.686^{* *}$ & $0.327^{* *}$ & $0.482^{* *}$ & $0.581^{* *}$ & $0.451^{* *}$ & 1.000 & & \\
& 0.000 & 0.000 & 0.000 & 0.000 & 0.000 & 0.000 & 0.000 & 0.000 & & \\
E & $0.687^{* *}$ & $0.688^{* *}$ & $0.434^{* *}$ & $0.773^{* *}$ & $0.728^{* *}$ & $0.724^{* *}$ & $0.803^{* *}$ & $0.439^{* *}$ & 1.000 & \\
& 0.000 & 0.000 & 0.000 & 0.000 & 0.000 & 0.000 & 0.000 & 0.000 & 0.000 & \\
F & $0.640^{* *}$ & $0.620^{* *}$ & $0.451^{* *}$ & $0.675^{* *}$ & $0.670^{* *}$ & $0.656^{* *}$ & $0.712^{* *}$ & $0.416^{* *}$ & $0.820^{* *}$ & 1.000 \\
& 0.000 & 0.000 & 0.000 & 0.000 & 0.000 & 0.000 & 0.000 & 0.000 & 0.000 & 0.000 \\
\hline
\end{tabular}

**. Correlation is significant at the 0.01 level (2-tailed).

*. Correlation is significant at the 0.05 level (2-tailed).

Sources: The data was processed, 2016.

The data used in this study have to be consolidated to investigate the comprehensive correlation among variables. Each of cross-country data provides as many as 125 respondents. Totally, there are 375 samples for the consolidated data from Italy, Turkey, and Indonesia. Hereafter, ten variables were computed to start the correlation analysis. According to the output shown in Table 3, it is discernibly known that the Table provides specific information regarding the correlation analysis among ten variables. As can be observed, generally found that there are positive and significant correlations among the employed variables. Hereby, Attitude 
(A) and behavioral intention (BI) shows a strong and significant $(p<0.01)$ correlation as 0.724 . The correlation between subjective norm (SN) and behavioral intention (BI) shows a relatively weaker value as 0.489 , but this value is positively significant $(p<0.01)$. Subjective norm $(\mathrm{SN})$ and attitude performed a bit stronger positive $(p<0.01)$ correlation as 0.604 . Perceived behavior control $(\mathrm{PBC})$ and behavior intention (BI) also performed a strong positive $(p<0.01)$ correlation as 0.623 . This also followed by the positive correlation $(p<0.01)$ between perceived behavior control $(\mathrm{PBC})$ and attitude $(\mathrm{A})$ as 0.601 . However, a weaker correlation but still significant $(p<0.01)$ is observed to exist in the correlation between perceived behavioral controlled (PBC) and subjective norm (SN) a 0.378 .

Furthermore, the correlation between relative advantage (RA) and behavior intention $(\mathrm{BI})$ showed a relatively strong positive $(p<0.01)$ value as 0.688 . While the variable of relative advantage $(\mathrm{RA})$ performed a stronger and positive $(p<0.01)$ value in terms of its correlation with attitude $(\mathrm{A})$ as 0.785 . The correlation of relative advantage (RA) with the subjective norm $(\mathrm{SN})$ and Perceived behavior control (BC) also result in positive and significant $(p<0.01)$ values as 0.569 and 0.632 successively. Also, the variable compatibility $(\mathrm{C} 1)$ shows positive and significant $(p<0.01)$ correlation with behavior intention $(\mathrm{BI})$, attitude $(\mathrm{A})$, perceived behavior control $(\mathrm{PBC})$ and relative advantage (RA). To get more comprehensive information concerning each variable correlation, Table 3 has been meticulously drawn. Moreover, the depth identification is conducted to seek the users' perception of using financial technology application as provided in summary statistics of respondent perspective as follow.

Table 4. Summary statistics of students' perspectives on RA, C1, C2, A

\begin{tabular}{|c|c|c|c|c|}
\hline \multirow{2}{*}{ Indicators } & \multirow{2}{*}{ Questions } & \multicolumn{3}{|c|}{ Countries' Mean } \\
\hline & & Italy & Turkey & Indonesia \\
\hline RA.1 & $\begin{array}{l}\text { Using Financial Technology application } \\
\text { would save time. }\end{array}$ & 4.35 & 3.97 & 3.88 \\
\hline RA.2 & $\begin{array}{l}\text { Using Financial Technology application } \\
\text { would save time, and it is important to me. }\end{array}$ & 4.05 & 3.75 & 3.54 \\
\hline RA.3 & $\begin{array}{l}\text { Using Financial Technology application } \\
\text { has more advantages. }\end{array}$ & 3.86 & 3.70 & 3.66 \\
\hline RA.4 & $\begin{array}{l}\text { Using Financial Technology application } \\
\text { has more advantages, and it is important } \\
\text { to me. }\end{array}$ & 3.70 & 3.51 & 3.56 \\
\hline \multicolumn{2}{|c|}{$\mu$ RA (RELATIVE ADVANTAGE) } & 3.99 & 3.73 & 3.66 \\
\hline C1.1 & $\begin{array}{l}\text { Using Financial Technology application } \\
\text { will fit well with my lifestyle. }\end{array}$ & 3.88 & 3.56 & 3.42 \\
\hline
\end{tabular}




\begin{tabular}{|c|c|c|c|c|}
\hline \multirow{2}{*}{ Indicators } & \multirow{2}{*}{ Questions } & \multicolumn{3}{|c|}{ Countries' Mean } \\
\hline & & Italy & Turkey & Indonesia \\
\hline $\mathrm{C} 1.2$ & $\begin{array}{l}\text { The Financial Technology application will } \\
\text { fit well with my lifestyle, and it is im- } \\
\text { portant to me. }\end{array}$ & 3.64 & 3.46 & 3.34 \\
\hline $\mathrm{C} 1.3$ & $\begin{array}{l}\text { Using Financial Technology application } \\
\text { will fit well with how I use it. }\end{array}$ & 3.76 & 3.66 & 3.44 \\
\hline C1.4 & $\begin{array}{l}\text { The Financial Technology application will } \\
\text { fit well with how I use it, and it is im- } \\
\text { portant to me. }\end{array}$ & 3.60 & 3.51 & 3.39 \\
\hline \multicolumn{2}{|c|}{$\mu$ C1 (COMPATABILITY) } & 3.72 & 3.55 & 3.40 \\
\hline $\mathrm{C} 2.1$ & $\begin{array}{l}\text { Financial Technology application is easy to } \\
\text { learn. }\end{array}$ & 3.81 & 3.56 & 3.45 \\
\hline $\mathrm{C} 2.2$ & $\begin{array}{l}\text { Easy to learn Financial Technology is } \\
\text { important to me. }\end{array}$ & 4.18 & 3.78 & 3.70 \\
\hline $\mathrm{C} 2.3$ & $\begin{array}{l}\text { Financial Technology application is easy to } \\
\text { operate. }\end{array}$ & 3.81 & 3.67 & 3.52 \\
\hline $\mathrm{C} 2.4$ & $\begin{array}{l}\text { Easy to operate Financial Technology ap- } \\
\text { plication is important to me. }\end{array}$ & 4.12 & 3.88 & 3.63 \\
\hline \multicolumn{2}{|c|}{$\mu$ C2 (COMPLEXITY) } & 3.98 & 3.72 & 3.57 \\
\hline A. 1 & $\begin{array}{l}\text { I feel using Financial Technology applica- } \\
\text { tion (e.g., PayPal, MoneyGram, Transfer- } \\
\text { Wise, etc.) is a wise idea. }\end{array}$ & 3.87 & 3.54 & 3.52 \\
\hline A. 2 & $\begin{array}{l}\text { I feel using Financial Technology applica- } \\
\text { tion is a good idea. }\end{array}$ & 4.10 & 3.63 & 3.75 \\
\hline A.3 & $\begin{array}{l}\text { I like to use Financial Technology applica- } \\
\text { tion. }\end{array}$ & 3.79 & 3.62 & 3.49 \\
\hline$\mu$ A (ATT & TUDE) & 3.92 & 3.60 & 3.59 \\
\hline
\end{tabular}

Notes: The mean scores are categorized into several classifications as follow; "Very low" with the mean score between 1.00 and 1.80, "Low" (1.81-2.60), "Neither high nor low" (2.61-3.40), "High" (3.41-4.20), and "Very high" (4.21-5.00).

Table 4 reflects the summary statistic of respondents' perception about relative advantage (RA), compatibility (C1), complexity (C2) and attitude (A). These constructs are commonly employed to seek the respondents' attitudes in using FinTech application in their daily life. Here, the model of decomposed theory of planned behavior can be seen through the additional construct such as relative advantage (RA), compatibility (C1) and complexity (C2). While attitude (A) previously known to exist in the theory of planned behavior as suggested by Ajzen, (1991). As can be observed in Table 4, thorough information is provided in terms of indicator, questions, and the countries' mean for Italian, Turkish and Indonesian respondents. 
As shown in Table 4, it is obviously seen that the scores for cross-countries' mean are categorized as high. This is due to the mean values of Italian, Turkish and Indonesian respondents regarding to relative advantage (RA) that are noted between 3.41 and 4.20. Hereby, Italian respondents show relative advantage as 3.99 and followed by Turkish and Indonesian respondents as 3.73 and 3.66 on average. Moreover, in the case of respondents' perception toward compatibility (C1) is reported as 3.72 for Italian respondents, 3.55 and 3.40 for Turkish and Indonesian respondents. These results indicate that there is a difference between Italian, Turkish and Indonesian respondents mean scores. Italian and Turkish respondents show countries' mean scores which are classified into high value. While on the other hand, Indonesian respondents' have shown neither high nor low value for their perception toward compatibility (C1) of FinTech application. In the case of complexity $(\mathrm{C} 2)$, there are almost the same perspectives among Italian, Turkish and Indonesian respondents. Hereby, it is observable that the countries' mean scores for the variable of complexity are categorized as high value (3.41-4.20). Moreover, respondents' perceptions about their attitudes (A) on FinTech applications are known in high values. The highest value is shown by Italian respondents, in which the mean score for Italian case is 3.92 followed by 3.60 for Turkish case and 3.59 in Indonesian case. In the next step, elaboration of respondents' perception toward financial technology application is conducted on normative influence (NI) and subjective norm (SN) as can be seen in Table 5 as follow.

Table 5. Summary statistic of students' perspectives on NI, SN

\begin{tabular}{|c|c|c|c|c|}
\hline \multirow{2}{*}{ Indicators } & \multirow{2}{*}{ Questions } & \multicolumn{3}{|c|}{ Countries' Mean } \\
\hline & & Italy & Turkey & Indonesia \\
\hline NI.1 & $\begin{array}{l}\text { My family would think that I should use Fi- } \\
\text { nancial Technology application. }\end{array}$ & 2.94 & 2.78 & 3.03 \\
\hline NI.2 & $\begin{array}{l}\text { Generally, I want to do what my family thinks } \\
\text { I should do. }\end{array}$ & 2.98 & 2.94 & 3.15 \\
\hline NI.3 & $\begin{array}{l}\text { Most people would think that I should use Fi- } \\
\text { nancial Technology application. }\end{array}$ & 3.14 & 3.18 & 3.13 \\
\hline NI.4 & $\begin{array}{l}\text { Generally, I want to do what most people think } \\
\text { I should do. }\end{array}$ & 2.66 & 2.85 & 3.10 \\
\hline \multicolumn{2}{|c|}{$\mu$ NI (NORMATIVE INFLUENCE) } & 2.93 & 2.94 & 3.10 \\
\hline SN.1 & $\begin{array}{l}\text { Most people who are important to me would } \\
\text { think that using Financial Technology applica- } \\
\text { tion is a wise idea. }\end{array}$ & 3.37 & 3.38 & 3.26 \\
\hline SN.2 & $\begin{array}{l}\text { Most people who are important to me would } \\
\text { think that using Financial Technology applica- } \\
\text { tion is a good idea. }\end{array}$ & 3.46 & 3.37 & 3.41 \\
\hline
\end{tabular}




\begin{tabular}{|c|c|c|c|c|}
\hline \multirow{2}{*}{ Indicators } & \multirow{2}{*}{ Questions } & \multicolumn{3}{|c|}{ Countries' Mean } \\
\hline & & Italy & Turkey & Indonesia \\
\hline SN.3 & $\begin{array}{l}\text { Most people who are important to me would } \\
\text { think I should use Financial Technology appli- } \\
\text { cation. }\end{array}$ & 3.29 & 3.21 & 3.18 \\
\hline SN.4 & $\begin{array}{l}\text { My families who are important to me would } \\
\text { think that using Financial Technology applica- } \\
\text { tion is a wise idea. }\end{array}$ & 3.12 & 3.00 & 3.13 \\
\hline SN.5 & $\begin{array}{l}\text { My families who are important to me would } \\
\text { think that using Financial Technology applica- } \\
\text { tion is a good idea. }\end{array}$ & 3.20 & 3.02 & 3.20 \\
\hline SN.6 & $\begin{array}{l}\text { My families who are important to me would } \\
\text { think I should use Financial Technology appli- } \\
\text { cation. }\end{array}$ & 3.07 & 3.02 & 3.11 \\
\hline \multicolumn{2}{|c|}{$\mu$ SN (SUBJECTIVE NORM) } & 3.25 & 3.17 & 3.21 \\
\hline
\end{tabular}

Notes: The mean scores are categorized into several classifications as follow; "Very low" with mean the score between 1.00 and 1.80, "Low" (1.81-2.60), "Neither high nor low" (2.61-3.40), "High" (3.41-4.20), and "Very high" (4.21-5.00).

Table 5 indicates the results of descriptive statistics regarding the normative influence (NI) and subjective norm (SN) of international respondents in Italian, Turkish and Indonesian case. In the survey conducted toward 375 respondents from three countries, it is known that the normative influence (NI) and subjective norm (SN) are being one of the most considerable factors for the respondents. This is due to the family and social factors which influence users' perception towards a specific issue. However, in a more specific result, it can be seen that Italian, Turkish and Indonesian users have shown neither high nor low value in regard to their perception of normative influence (NI). Here, the Italian mean score is noted to be 2.93 while Turkish's and Indonesian's mean scores are 2.94 and 3.10. The similar results are also found in the respondents' perception about the subjective norm (SN). Italian mean score for subjective norm is 3.25 on average followed by 3.17 for Turkish case and 3.21 in Indonesian case. The tendency of neither high nor low of normative influence (NI) and subjective norm (SN) emerges due to respondents' belief that social factors actually do not bring a huge impact toward their decision as FinTech users. 
Table 6. Summary statistic of students' perspective on E, F, PBC

\begin{tabular}{|c|c|c|c|c|}
\hline \multirow{2}{*}{ Indicators } & \multirow{2}{*}{ Questions } & \multicolumn{3}{|c|}{ Countries' Mean } \\
\hline & & Italy & Turkey & Indonesia \\
\hline E.1 & $\begin{array}{l}\text { I could easily to operate Financial Technology } \\
\text { application on my own. }\end{array}$ & 3.99 & 3.60 & 3.50 \\
\hline E. 2 & $\begin{array}{l}\text { Being able to operate Financial Technology ap- } \\
\text { plication is important to me. }\end{array}$ & 3.97 & 3.75 & 3.52 \\
\hline E.3 & $\begin{array}{l}\text { I know enough to operate Financial Technology } \\
\text { application. }\end{array}$ & 3.79 & 3.41 & 3.41 \\
\hline E.4 & $\begin{array}{l}\text { Knowing enough to operate Financial Technol- } \\
\text { ogy application is important to me. }\end{array}$ & 3.98 & 3.90 & 3.66 \\
\hline E.5 & $\begin{array}{l}\text { I would feel comfortable using Financial Tech- } \\
\text { nology application. }\end{array}$ & 3.99 & 3.70 & 3.39 \\
\hline E. 6 & $\begin{array}{l}\text { Being comfortable using Financial Technology } \\
\text { application on my own is important to me. }\end{array}$ & 4.18 & 3.82 & 3.65 \\
\hline \multicolumn{2}{|c|}{$\mu \mathrm{E}$ (EFFICACY) } & 3.98 & 3.70 & 3.52 \\
\hline F.1 & $\begin{array}{l}\text { I have the network to use Financial Technology } \\
\text { application. }\end{array}$ & 3.97 & 3.65 & 3.56 \\
\hline F.2 & $\begin{array}{l}\text { Having the network to use Financial Technol- } \\
\text { ogy application is important to me. }\end{array}$ & 4.10 & 3.93 & 3.62 \\
\hline F.3 & $\begin{array}{l}\text { I have the time to use Financial Technology } \\
\text { application. }\end{array}$ & 3.78 & 3.58 & 3.39 \\
\hline F.4 & $\begin{array}{l}\text { Having the time to use Financial Technology } \\
\text { application is important to me. }\end{array}$ & 3.95 & 3.74 & 3.46 \\
\hline F. 5 & $\begin{array}{l}\text { I have enough money to use Financial Technol- } \\
\text { ogy application. }\end{array}$ & 3.47 & 3.38 & 3.25 \\
\hline F.6 & $\begin{array}{l}\text { Having enough money to use Financial Tech- } \\
\text { nology application is important to me. }\end{array}$ & 3.78 & 3.76 & 3.55 \\
\hline \multicolumn{2}{|c|}{$\mu$ F (FACILITATING CONDITION) } & 3.84 & 3.67 & 3.47 \\
\hline PBC.1 & $\begin{array}{l}\text { I would be able to operate Financial Technol- } \\
\text { ogy application. }\end{array}$ & 4.23 & 3.60 & 3.59 \\
\hline PBC.2 & $\begin{array}{l}\text { I have the resources to use Financial Technol- } \\
\text { ogy application. }\end{array}$ & 4.15 & 3.38 & 3.57 \\
\hline PBC.3 & $\begin{array}{l}\text { I have the knowledge to use Financial Technol- } \\
\text { ogy application. }\end{array}$ & 3.83 & 3.39 & 3.45 \\
\hline PBC.4 & $\begin{array}{l}\text { I have the ability to use Financial Technology } \\
\text { application. }\end{array}$ & 3.99 & 3.65 & 3.49 \\
\hline$\mu \mathrm{PBC}$ & PERCEIVED BEHAVIORAL CONTROL) & 4.05 & 3.51 & 3.52 \\
\hline
\end{tabular}

Notes: The mean scores are categorized into several classifications as follow; "Very low" with the mean score between 1.00 and 1.80, "Low" (1.81-2.60), "Neither high nor low" (2.61-3.40), "High" (3.41-4.20), and "Very high" (4.21-5.00). 
The elaboration also conducted toward the respondents' perception of efficacy (E), facilitating condition (F), and perceived behavior control (PBC). As shown by the results in Table 6, it is clearly known that the cross-countries respondents performed a relatively high value of their perception on efficacy (E). In the Italian case, the efficacy (E) mean score is 3.98 followed by 3.70 for Turkish case and 3.52 for Indonesian case. In the construct of facilitating condition (F), the high value is also found in the three countries, in which the majority of Italian respondents have noted mean score as 3.84 on average, Turkish respondents as 3.67 and 3.47 for Indonesian respondents on average. Further, the same condition can be found in the perceived behavior control (PBC), where Italian, Turkish, and Indonesian respondents gave a relatively high mean score on average (the cross-countries mean scores are categorized between 3.41-4.20)

Table 7. Summary statistic of students' perspectives on BI

\begin{tabular}{llrrr}
\hline \multirow{2}{*}{ Indicators } & \multicolumn{1}{c}{ Questions } & \multicolumn{3}{c}{ Countries' Mean } \\
\cline { 3 - 5 } & Italy & Turkey & Indonesia \\
\hline BI.1 & $\begin{array}{l}\text { I plan to use Financial Technology application } \\
\text { (e.g., PayPal, MoneyGram, TransferWise, etc.) }\end{array}$ & 3.88 & 3.57 & 3.38 \\
BI.2 & $\begin{array}{l}\text { I intend to use Financial Technology applica- } \\
\text { tion within the next three months. }\end{array}$ & 3.63 & 3.14 & 3.22 \\
BI.3 & $\begin{array}{l}\text { I intend to use Financial Technology applica- } \\
\text { tion within the next three months. }\end{array}$ & 3.32 & 3.11 & 3.22 \\
\multicolumn{1}{l}{ B BI (BEHAVIORAL INTENTION) } & 3.61 & 3.27 & 3.27 \\
\hline
\end{tabular}

Notes: The mean scores are categorized into several classifications as follow; "Very low" with the mean score between 1.00 and 1.80, "Low" (1.81-2.60), "Neither high nor low" (2.61-3.40), "High" (3.41-4.20), and "Very high" (4.21-5.00).

In terms of behavioral intention (BI) of using financial technology application, only respondents from Italy showed a relatively high mean score rather than Turkish and Indonesian respondents. It is clearly noted that Italian respondents have shown a mean score as 3.61 followed by 3.27 for Turkish and Indonesian respondents. This condition leads to a general conclusion where the intention to use financial technology is higher among Italian users. Also, the fully integrated of economic activity within the area of European Union (EU) is one of the supporting factors in order to make Italian users more familiar and have higher intention with financial technology application. Nevertheless, Turkey and Indonesia economy also performed a good inclination for the last several years. Even though the results of cross-country analysis show Turkish and Indonesian case have shown neither high nor low value of mean score (the mean scores are between 2-61-3.40). 


\section{Discussion}

This study is officially aimed to respond the recent call for research on the financial technology industry. In particular, firms which start their business in terms of startup business model will eventually learn to expand their business scale (Lussier, 1996). The perception of users is clearly needed to describe how big the intentions and interests of users with respect to the phenomenon of financial technology (FinTech) application as operated by FinTech startup firms. Therefore, it can be noted that this study also contributes to the works of literature by describing the perception of users about the financial technology startup firms in three different countries.

Recall back to the ecological approaches to organization as revealed by Baum \& Shipilov (2006), a new organization tend to do an adjustment with its ecosystem and population. A FinTech startup firm is supposed as a breakdown of an ecological environment in financial industry, in which banking industry has played in a longterm period in this marketplace. However, the presence of FinTech is a typically different from the ecological approaches, in which a new entity should have to adapt their business model by doing some benchmarking and or mimicking to gain legitimacy (Dapp, 2014). Hereby, startup business model tries to build something new, in which the players in the financial industry have made a new way of doing financial service and transaction without depending on bank as the main actors.

After completing the goal to gain legitimacy, FinTech startup firms should have to be focused on their market niche. Here, they compete with the well-established firms which have firstly entered the market. However, banks as the first movers in the financial service industry should not have to be considered as competitor, but the collaborator. As said by Zardini, Ricciardi, \& Rossignoli, (2015) relational capital of IT is crucially important in creating a strong competitive advantage as a strategic value. Rossignoli, Gatti, \& Agrifoglio, (2016) point out that interplay between the developments of IT should have to be considered as the important framework for organizational innovation. Therefore, the more business entity able to utilize the information technology, the more it can gain the advantages in market competition. It is clear that in the case of FinTech startup firms, the new business entities are supposed to gain advantages from the radical innovation resulted in from the combination between the financial industry and technology indicators.

Referring back to the results of behavioral intention (BI) of using FinTech application among respondents in three countries, it is obviously known that Turkey and Indonesian users have shown a relatively lower intention rather than Italian users. Instead of the huge number of population in Turkey and Indonesia, these two countries have just started the integration of technology and economy. 
Nonetheless, Italy, as the member of European Union has benefited a long-term benefit of combining financial and technology with its economy. Some factors which make the intention of Turkish and Indonesian users lower than Italy also caused by the type of psychological risk, which arises from the general facts that users do not know which of among the available information from the providers are trustworthy. This is common in emerging country, where the rate of cyber-crime is still high. This condition is relevant to the study of Bobbitt \& Dabholkar, (2001) who show that there is a certain degree of psychological risk that can be attributed to the unknown entity where they buy the services or products.

In order to protect the users' security when doing the transaction with FinTech application, the government regulation is totally needed to support a sound of FinTech system. In this regard, regulation should have to be considered as the protection for users. Also, this circumstance is beneficially important to FinTech startup firms where the promoting regulation will be positively connected to promotion in the marketplace (Sironi, 2016). As revealed by the empirical results in three countries (Italy, Turkey, Indonesia), the regulatory environment within a particular country is becoming less favorable to FinTech. In this case, the regional area is important, where a startup company that is established in a strategic regional member state may have the key to enter the licensing right obtained in one to another country. Thus, the interconnected pattern of work can be fully achieved.

In more comprehensive views, FinTech has brought a new opportunity in the financial service industry as a game changer. The position of FinTech startup firms, particularly as small medium enterprises (SMEs) generally focus on the single-purpose solution. If it is compared to the well-established and big financial institutions, of course, the small firm would not be able to rapidly gain the equal performance. However, in actual, the performance and the procedures of business transformation in the traditional financial business model even often slowed down by a legacy process which is influenced by the obsolete system, and inert culture. Therefore, it is the opportunity of financial technology to start the radical innovation in disrupting the problem in the traditional financial business model (Chishti \& Barberis, 2016).

The reaction of banks as the traditional players in financial industry also detected as one of the catalysts in boosting the FinTech performance in market competition. Banks are currently very aware of the presence of FinTech in the marketplace (Dapp, 2014). This happens due to financial technology abilities in challenging and addressing the traditional business model in a new thing (e.g., bank commonly offering and increasing SMEs lending in order to capture some available 
marketplaces). However, the inclusive products provided by FinTech are not only positively responded by the users, in which banks, in the same way react to the emerging of financial technology as one of the ways to move from the comfort zone. In this situation, the bank will be positively accepting these changes by employing internal innovation and development model for their services. Instead of pursuing a radical innovation, the bank may behave to directly acquire marketplace lender on the spot.

\section{CONCLUSION REMARKS}

This study summarizes the descriptive data to illustrate the respondents' perception of financial technology (FinTech) application regarding the utilization of decomposed model of the theory of planned behavior. Also, this study is focused on the efforts of elaborating the phenomenon of start-up business model, particularly the combination of financial and technology industry. Referring back to the results of descriptive statistic, it is noted that principally the model of FinTech startup business has attracted many consumers. This is considered by the high level of behavior intention as shown by the respondents. However, in case of more specific comparison, Italian (3.61) user has performed a relatively higher intention rather than Turkish (3.27) and Indonesian (3.27). These three countries are specifically different in terms of demographical profiles, in which each economic characteristic of the observed country is difference according to their regional economy areas. However, it can be reported that the phenomenon of glancing meteor of financial technology startup firms will be increasing in the next consecutive years.

\section{REFERENCES}

Ajzen, I. (1985). From intentions to actions: a theory of planned behavior. In Action Control (pp. 11-39). https://doi.org/10.1007/978-3-642-69746-3_2

Ajzen, I. (1991). The theory of planned behavior. Organizational Behavior and Human Decision Processes, 50(2), 179-211. https://doi.org/10.1016/07495978(91)90020-T

Alfansi, L., \& Sargeant, A. (2000). Market segmentation in the Indonesian banking sector : the relationship between demographics and desired customer benefits. International Journal of Bank Marketing, 18(2), 64-74. https://doi.org/10.1108/02652320010322976

Au, Y. A., \& Kauffman, R. J. (2008). The economics of mobile payments: Understanding stakeholder issues for an emerging financial technology application. Electronic Commerce Research and Applications, 7(2), 141-164. https://doi.org/10.1016/j.elerap.2006.12.004

Baum, J. A. C., \& Shipilov, A. V. (2006). Ecological approaches to organizations 
introduction. In Sage Handbook for Organization Studies (pp. 55-110).

Bobbitt, M. L., \& Dabholkar, P. A. (2001). Integrating attitudinal theories to understand and predict use of technology-based self-service. International Journal of Service Industry Management, 12(5), 423-450. https://doi.org/10.1108/EUM0000000006092

Chishti, S., \& Barberis, J. (2016). The fintech book: the financial technology handbook for investors, entrepreneurs and visionaries. Chichester-UK: John Wiley \& Sons, Inc.

Dapp, T. (2014). Fintech - the digital (r)evolution in the financial sector. Deutsche Bank Research, (Frankfurt am Main), 39. Retrieved from www.dbresearch.com

Ekufu, T. K. (2012). Predicting cloud computing Technology adopting by organization: An empirical integration of Technology accepting model and theory of planned behavior. ProQuest LLC.

Fishbein, M. \& Ajzen, I. (1975). Belief, attitude, attitude, intention and behavior: An introduction to theory of research. Reading, MA : Addison-Wesley Addison-Wesley, 578.

Hoon, L. S., \& Lee, D. (2015). FinTech-conversions of finance industry based on ICT. Journal of the Korea Convergence Society, 6(3), 97-102. https://doi.org/10.15207/JKCS.2015.6.3.097

Hunt, S. D., \& Morgan, R. M. (1995). The comparative advantage theory of competition. Journal of Marketing, 59(2), 1. https://doi.org/10.2307/1252069

ITA. (2016). 2016 top markets report financial technology. International trade Administration. Retrieved from www.trade.gov/topmarkets

Kamaludin, Darmansyah, \& Usman, B. (2015). Determinan non performing loan (NPL) pada industri perbankan (bukti Empiris perusahaan go publik di bursa efek Indonesia). Jurnal Aplikasi Manajemen, 13(4), 547-556.

Kask, J., \& Linton, G. (2013). Business mating: when start-ups get it right. Journal of Small Business \& Entrepreneurship, 26(5), 511-536. https://doi.org/10.1080/08276331.2013.876765

Lueg, R., Malinauskaite, L., \& Marinova, I. (2014). The vital role of business processes for a business model: The case of a startup company. Problems and Perspectives in Management, 12(4), 213-220.

Luor, T., Lu, H., Johanson, R. E., \& Yu, H. (2012). Minding the gap between first and continued usage of a corporate e-earning English-language program. International Journal of Technology and Human Interaction, 8(1), 55-74. https://doi.org/10.4018/jthi.2012010104

Lussier, R. N. (1996). A startup business success versus failure prediction model for the retail industry. The Mid - Atlantic Journal of Business, 32(2), 79. Retrieved from 
http://search.proquest.com/docview/203734509?accountid=48385

McKinsey. (2015). Cutting through the finTech noise: markers of success, imperatives for banks. McKinsey and Company, 1-18. Retrieved from http://www.mckinsey.com/ /media/mckinsey/industries/financial services/our insights/cutting through the noise around financial technology/cutting-through-the-fintech-noise-full-report.ashx

Mellon, B. of N. Y. (2015). Innovation in payments: the future is fintech. The Bank of Newyork. New York.

Nkongolo-Bakenda, J.-M. (2002). Inter-firm networking propensity in small and medium-sized enterprises ( SMEs ). The Journal of Entrepreneurial Finance, 7(1), 99-122. Retrieved from http://digitalcommons.pepperdine.edu/jef/vol7/iss1/8/

Nurazi, R., Kananlua, P. S., \& Usman, B. (2015). The effect of google trend as determinant of return and liquidity in Indonesia Stock Exchange. Journal Pengurusan, 45(3), 131-142.

Nurazi, R., \& Usman, B. (2015). Public attention and financial information as determinant of firms performance in the telecommunication sector. Jurnal Keuangan dan Perbankan, 19(2), 235-251.

Nurazi, R., \& Usman, B. (2016). Bank stock returns in responding the contribution of fundamental and macroeconomic effects. JEJak: Jurnal Ekonomi Dan Kebijakan, 9(1), 134-149. https://doi.org/10.15294/jejak.v9i1.7191

Nurazi, R., Usman, B., \& Kananlua, P. S. (2016). Does bid/ask spread react to the increase of internet search traffic. International Research Journal of Business Studies, 8(3), 181-196.

Philippon, T. (2016). The Fintech Opportunity. NBER Working Paper Series. https://doi.org/10.1017/CBO9781107415324.004

Ricciardi, F., Rossignoli, C., \& Zardini, A. (2013). Factors influencing the strategic value of IT: a literature review. In S. M. and S. science Institute (Ed.), Lecture Notes in management Science (pp. 86-91). Singapore: Singapore Management and Sports science Institute. Retrieved from http://hdl.handle.net/10807/47835

Robehmed, N. (2013). What is a startup? Retrieved October 18, 2017, from https://www.forbes.com/sites/natalierobehmed/2013/12/16/what-is-astartup/\#1fd42a2b4044

Rogers, E. M. (1995). Diffusion of innovations. Macmillian Publishing Co. https://doi.org/citeulike-article-id:126680

Rossignoli, C., Gatti, M., \& Agrifoglio, R. (2016). Organizational innovation and change: managing information and technology. (C. Rossignoli, M. Gatti, \& R. Agrifoglio, Eds.). Springer International Pubishing Switzerland.

Sharma, D. (2012). Does technology lead to better financial performance? a study 
of Indian commercial banks. Managing Global Transitions, 10, 3-28.

Retrieved from http://ideas.repec.org/a/mgt/youmgt/v10y2012i1p003028.html

Shih, Y.-Y., \& Fang, K. (2004). The use of a decomposed theory of planned behavior to study Internet banking in Taiwan. Internet Research, 14(3), 213-223. https://doi.org/10.1108/10662240410542643

Shimp, T. A., \& Kavas, A. (1984). The theory of reasoned action applied to coupon usage. Journal of Consumer Research, 11(3), 795-809. https://doi.org/10.1086/209015

Sironi, P. (2016). FinTech innovation: from robo-advisors to goal based investing and gamification. FinTech Innovation, 1-18. https://doi.org/10.1002/9781119227205.ch1

Solaimani, S., \& Bouwman, H. (2012). A framework for the alignment of business model and business processes: a generic model for trans-sector innovation. Business Process Management Journal, 18(4), 655-679. https://doi.org/10.1108/14637151211253783

Tan, M., \& Teo, T. S. H. (2000). Factors Influencing the Adoption of Internet Banking. Journal of the Association for Information Systems, 1(5), 1-42. https://doi.org/10.1016/j.elerap.2008.11.006

Taylor, S., \& Todd, P. (1995). Decomposition and crossover effects in the theory of planned behavior: a study of consumer adoption intentions. International Journal of Research in Marketing, 12(2), 137-155. https://doi.org/10.1016/0167-8116(94)00019-K

Usman, Berto, A Glimpse of Entrepreneurial Intention: Empirical Finding of International Students' Perspectives in Turkey (April 29, 2016). International Students Social Sciences Congress, 29 April - 1 May, 2016 Konya - Turkey. Available at SSRN: https://ssrn.com/abstract=2822927

Usman, B., \& Tandelilin, E. (2014). Internet search traffic and its influence on liquidity and returns of Indonesian stocks: an empirical study. Journal of Indonesian Economy and Business, 29(3), 203-221.

Vasiljeva, T., \& Lukanova, K. (2016). Commercial banks and fintech companies in the digital transformation: challenges for the future. Journal of Business Management, (11), 25-33.

Wentzel, J. P., Diatha, K. S., \& Yadavalli, V. (2013). An application of the extended technology acceptance model in understanding technology-enabled financial service adoption in South Africa. Development Southern Africa, 30(4-05), 659-673. https://doi.org/10.1080/0376835X.2013.830963

World Economic Forum. (2015). The future of fintech: a paradigm shift in small business finance. Switzerland. Retrieved from www.weforum.org

Zardini, A., Ricciardi, F., \& Rossignoli, C. (2015). The relational capital of the IT department: measuring a key resource for creating strategic value. Journal of 
Intellectual Capital, 16(4), 835-859. https://doi.org/10.1108/JIC-12-20140132 